\title{
OCCURRENCE OF HEAVY METALS AND ANTIBIOTIC RESISTANCE IN BACTERIA FROM INTERNAL ORGANS OF AMERICAN BULLFROG (Rana catesbeiana) RAISED IN MALAYSIA
}

\author{
Lee SW (1), Najiah M (1, 2), Wendy W (1), Nadirah M (1), Faizah SH (2)
}

(1) Department of Fisheries and Aquaculture, Faculty of Agrotechnology and Food Science, University of Malaysia at Terengganu, Kuala Terengganu, Terengganu, Malaysia; (2) Institute of Tropical Aquaculture, University of Malaysia at Terengganu, Kuala Terengganu, Terengganu, Malaysia.

ABSTRACT: A total of 40 bacteria have been successfully isolated from internal organs of the American bullfrog (Rana catesbeiana) raised in Malaysia, namely, eight isolates of Aeromonas spp., 21 of Edwardsiella spp., six of Flavobacterium spp. and five of Vibrio spp. In terms of antibiotic susceptibility testing, each isolate was tested against 21 antibiotics, resulting in 482 (57.3\%) cases of sensitivity and 61 (7.3\%) cases of partial sensitivity. Meanwhile, 297 (35.4\%) bacterial isolates were registered as resistant. The multiple antibiotic resistance (MAR) index of each bacterial species indicated that bacteria from raised bullfrogs have been exposed to tested antibiotics with results ranging from 0.27 to 0.39 . Additionally, high percentages of heavy metal resistance among these isolates were observed, with values ranging from 85.0 to $100.0 \%$. The current results provided us information on bacterial levels of locally farmed bullfrogs exposed to copper, cadmium, chromium as well as 21 types of antibiotics.

KEY WORDS: Rana catesbeiana, antibiogram, heavy metal resistance, multiple antibiotic resistance, Aeromonas spp., Edwardsiella spp., Flavobacterium spp., Vibrio spp.

CONFLICTS OF INTEREST: There is no conflict.

FINANCIAL SOURCE: University of Malaysia at Terengganu.

\section{CORRESPONDENCE TO:}

NAJIAH MUSA, Department of Fisheries and Aquaculture, Faculty of Agrotechnology and Food Science, University of Malaysia at Terengganu, 21030 Kuala Terengganu, Terengganu, Malaysia. Phone: +6096683360. Fax: +6096683434. Email: najiah@umt.edu.my. 


\section{INTRODUCTION}

American bullfrog (Rana catesbeiana), formerly known as the North American bullfrog, was first introduced into Malaysia through Taiwan for aquaculture purposes. Farmers prefer to raise this bullfrog since it is able to adapt in various environments and is easy to breed, besides its biological attributes such as large size and muscle mass. Nowadays, Malaysia is capable of producing merely 100 tons per month to meet both local and international market demands. There were many reports that this raised frog is susceptible to bacterial diseases that could cause high mortality and significant economic losses (1). One of these infections was the red-leg syndrome provoked by Aeromonas hydrophila $(1,2)$. However, a study failed to isolate $A$. hydrophila from a bullfrog (Rana catesbeiana) that suffered from the same syndrome (3). The authors concluded that Proteus vulgaris was the causative agent of the redleg syndrome in that case. Other bacteria that were commonly found infecting bullfrogs were Edwardsiella tarda and Flavobacterium spp. (4). Currently, no scientific documentation has recorded heavy metal or antibiotic resistance of bacteria isolated from bullfrog farms in Malaysia. Therefore, the present study was conducted to evaluate the antibiotic and heavy metal tolerance of these microorganisms obtained from internal organs of farmed American bullfrogs in Malaysia.

Twenty American bullfrogs weighing between 250 to $300 \mathrm{~g}$ were sampled from a frog farm during monsoon season, in December 2008. The animals were euthanized by a standard procedure (5). Aseptically, swabs were taken from each body part such as the eyes, kidney, liver and abdominal fluid of frogs by using sterile cotton bud; subsequently, spread-plate technique was employed with several selective agars such as cytophaga agar (CA), glutamate starch pseudomonas (GSP), thiosulfate citrate bile salt (TCBS) and xylose lysine deoxycholate agar (XLD) (Oxoid, England). Plates were incubated at room temperature $\left(28\right.$ to $\left.30^{\circ} \mathrm{C}\right)$ - since this the optimal growth temperature for mesophilic bacteria - for 24 to 48 hours. Colonies were then selected and kept in TSA deep tube for further studies.

Antibiotic susceptibility testing was conducted according to Kirby and Bauer disk diffusion method (6) by employing Mueller-Hinton agar (Oxoid, England). Antibiotics utilized were: $15 \mu \mathrm{g}$ of erythromycin (E); $100 \mu \mathrm{g}$ of spiramycin (SP); $30 \mu \mathrm{g}$ of oxytetracycline (OT); $15 \mu \mathrm{g}$ of furazolidone (FR); $30 \mu \mathrm{g}$ of kanamycin (K); $30 \mu \mathrm{g}$ of nalidixic acid (NA); $30 \mu \mathrm{g}$ of chloramphenicol (C); $10 \mu \mathrm{g}$ of ampicillin (AMP); $25 \mu \mathrm{g}$ of sulfamethoxazole (RL); $25 \mu \mathrm{g}$ of amoxicillin (AML); $25 \mu \mathrm{g}$ of colistin sulfate (CT); 30 
$\mu \mathrm{g}$ of doxycycline (DO); $30 \mu \mathrm{g}$ of florfenicol (FFC); $30 \mu \mathrm{g}$ of flumequine (UB); $50 \mu \mathrm{g}$ of fosfomycin (FOS); $15 \mu \mathrm{g}$ of lincomycin (MY); $50 \mu \mathrm{g}$ of nitrofurantoin (F); $30 \mu \mathrm{g}$ of novobiocin (NV); $15 \mu \mathrm{g}$ of oleandomycin (OL); $2 \mu \mathrm{g}$ of oxolinic acid (OA) and $100 \mu \mathrm{g}$ of spiramycin (SP). The multiple antibiotic resistance (MAR) index of isolates against tested antibiotics was calculated based on the following formula (7):

MAR index $=X /(Y \times Z)$

$\mathrm{X}$ : total of bacteria resistant to antibiotics;

Y: total of antibiotics used in the study;

Z: total of isolates.

A MAR index value equal to or less than 0.2 indicated antibiotics that had been seldom or never used, in terms of treatment, whereas a value greater than 0.2 suggested that the animal had been highly exposed to those antibiotics. Minimum inhibitory concentrations (MIC) of three heavy metals for the present bacterial isolates were determined by two-fold agar dilution method (8). $\mathrm{CdCl}, \mathrm{CuSO}_{4}$ and $\mathrm{K}_{2} \mathrm{Cr}_{2} \mathrm{O}_{7}$ were added to tryptic soy agar (TSA) (Merck, Germany) where the concentration of $\mathrm{Cu}^{2+}$ ranged from 150 to $2,400 \mu \mathrm{g} / \mathrm{mL}$ whereas concentrations of both of $\mathrm{Cd}^{2+}$ and $\mathrm{Cr}^{6+}$ were between 25 and $400 \mu \mathrm{g} / \mathrm{mL}$. Isolates were subsequently streaked on media that received previously the metals. Bacterial isolates were considered resistant if they were able to grow at concentration of $100 \mu \mathrm{g} / \mathrm{mL}\left(\mathrm{Cd}^{2+}\right.$ and $\left.\mathrm{Cr}^{6+}\right)$ and $600 \mu \mathrm{g} / \mathrm{mL}\left(\mathrm{Cu}^{2+}\right)$ after 48-hour incubation at room temperature (9).

In the present study, a total of 40 bacterial isolates were successfully isolated comprising eight isolates of Aeromonas spp., 21 of Edwardsiella spp., six of Flavobacterium spp. and five of Vibrio spp. A total of 482 cases (57.3\%) were reported as sensitive, whereas 61 (7.3\%) and 297 (35.4\%) were, respectively, partially sensitive and resistant. In the present study, all bacterial isolates were sensitive to flumequine and oxolinic acid against Aeromonas spp., florfenicol against Edwardsiella spp. and nitrofurantoin against Vibrio spp. (Table 1). In addition, more than $70 \%$ of the bacterial isolates were sensitive to furazolidone and chloramphenicol. On the other hand, only 5\% of Edwardsiella spp. and Flavobacterium spp. were sensitive to lincomycin whereas 10\% of Aeromonas spp. and $12.5 \%$ of Vibrio spp. were sensitive to this antibiotic. MAR values were ranging from 0.27 to 0.39 , Vibrio spp. presented the highest MAR value (0.39) while Aeromonas spp. revealed the lowest one (0.27) (Table 2). All isolates were resistant 
to chromium whereas $85 \%$ were resistant to both copper and cadmium. The occurrence of antibiotic and heavy metal resistance among the studied bacterial isolates may be due to untreated sewage, industrial wastes and agricultural activities near frog farms (8).

MAR indexes of the present work revealed that bacteria from locally raised bullfrogs may have been exposed to tested antibiotics. It has been reported that the MAR index of bacteria from a catfish pond, near a river in which antibiotic was commonly used as treatment, was as high as 0.76 (10). In the current study, flumequine was found to be the most effective antibiotic for controlling bacterial disease in these frog farms. Other antibiotics that were also effective were oxolinic acid, florfenicol, nitrofurantoin, chloramphenicol and furazolidone. However, Malaysian government has banned oxolinic acid, nitrofurantoin, chloramphenicol and furazolidone for aquaculture use. Therefore, based on published studies, farmers should use other drugs that are also effective for treatment and prophylactic purposes.

Currently, local frog farmers employ amoxicillin to treat bullfrog diseases. The present results proven that amoxicillin is no longer effective, since not more than $27.5 \%$ of bacterial isolates were sensitive to it. These findings constitute an alert to antibiotic resistance of Aeromonas spp., Edwardsiella spp., Flavobacterium spp. and Vibrio spp. Noticeably, the majority of isolates were resistant to tested heavy metals, namely, cadmium, chromium and copper. Since the frog farm that provided experimental animals was located in a palm oil plantation, its water source could possibly be contaminated with heavy metals due to agricultural activities. A study reported that polluted and unpolluted water sources in Chile were reservoirs of Aeromonas spp. resistant to both antibiotics and heavy metals (8).

Herein, we could conclude that the water source of our frog farm could contain bacteria resistant to antibiotics and heavy metals. As a consequence, these bacteria could transfer their antibiotic and heavy metal resistance to other bacteria from aquaculture sites. These observations indicated a significant occurrence of bacteria in internal organs of frogs, with high incidence of resistance against antibiotics and heavy metals, which may risk frog farms and the public health. Further studies should be carried out to reveal the incidence of antibiotic and heavy metal resistance among bacteria isolated from Malaysian aquaculture sites as well as the role of plasmids in the development of heavy metals and antibiotic resistance patterns. 
Lee SW et al. Occurrence of heavy metals and antibiotic resistance in bacteria from internal organs of American Bullfrog (Rana catesbeiana) raised in Malaysia. J Venom Anim Toxins incl Trop Dis. 2009;15(2):357

Table 1. Percentage of sensitivity of Aeromonas spp., Edwardsiella spp., Flavobacterium spp. and Vibrio spp. against 21 antibiotics

\begin{tabular}{|c|c|c|c|c|}
\hline $\begin{array}{l}\text { Antibiotic } \\
(\mu \mathrm{g} / \mathrm{disk})\end{array}$ & Aeromonas spp. & Edwardsiella spp. & Flavobacterium spp. & Vibrio spp. \\
\hline Oxolinic acid (2) & 100.0 & 80.0 & 90.0 & 92.5 \\
\hline Ampicillin (10) & 35.0 & 27.5 & 42.5 & 32.5 \\
\hline Erythromycin (15) & 35.0 & 25.0 & 37.5 & 32.5 \\
\hline Furazolidone (15) & 90.0 & 90.0 & 80.0 & 75.0 \\
\hline Lincomycin (15) & 10.0 & 5.0 & 5.0 & 12.5 \\
\hline $\begin{array}{c}\text { Oleandomycin } \\
(15)\end{array}$ & 12.5 & 17.5 & 10.0 & 10.0 \\
\hline Amoxicillin (25) & 27.5 & 20.0 & 25.0 & 20.0 \\
\hline $\begin{array}{c}\text { Colistin sulfate } \\
\text { (25) }\end{array}$ & 60.0 & 55.0 & 45.0 & 50.0 \\
\hline $\begin{array}{c}\text { Sulfamethoxazole } \\
(25)\end{array}$ & 52.5 & 42.5 & 50.0 & 50.0 \\
\hline $\begin{array}{c}\text { Chloramphenicol } \\
(30)\end{array}$ & 87.5 & 75.0 & 87.5 & 90.0 \\
\hline Doxycycline (30) & 52.5 & 50.0 & 50.0 & 50.0 \\
\hline Florfenicol (30) & 90.0 & 100.0 & 92.5 & 92.5 \\
\hline Flumequine (30) & 100.0 & 100.0 & 100.0 & 100.0 \\
\hline Kanamycin (30) & 60.0 & 55.0 & 80.0 & 80.0 \\
\hline Nalidixic acid (30) & 90.0 & 75.0 & 62.5 & 65.0 \\
\hline Novobiocin (30) & 60.0 & 72.5 & 32.5 & 32.5 \\
\hline $\begin{array}{c}\text { Oxytetracycline } \\
\text { (30) }\end{array}$ & 30.0 & 25.0 & 32.5 & 32.5 \\
\hline Tetracycline (30) & 45.0 & 50.0 & 90.0 & 50.0 \\
\hline $\begin{array}{c}\text { Nitrofurantoin } \\
(50)\end{array}$ & 67.5 & 52.5 & 95.0 & 100.0 \\
\hline Fosfomycin, (50) & 60.0 & 60.0 & 62.5 & 65.0 \\
\hline Spiramycin (100) & 30.0 & 42.5 & 32.5 & 32.5 \\
\hline
\end{tabular}

Table 2. MAR index of bacteria in the present study

\begin{tabular}{c|c}
\hline Bacterial Species & Multiple Antibiotic Resistance Index \\
\hline Aeromonas spp. & 0.27 \\
\hline Edwardsiella spp. & 0.31 \\
\hline Flavobacterium spp. & 0.36 \\
\hline Vibrio spp. & 0.39 \\
\hline
\end{tabular}


Lee SW et al. Occurrence of heavy metals and antibiotic resistance in bacteria from internal organs of American Bullfrog (Rana catesbeiana) raised in Malaysia. J Venom Anim Toxins incl Trop Dis. 2009;15(2):358

\section{ACKNOWLEDGEMENTS}

This project was supported by the University of Malaysia at Terengganu, Malaysia.

\section{REFERENCES}

1. Cunningham AA, Langton TE, Bennett PM, Lewin JF, Drury SE, Gough R, Macgregor SK. Pathological and microbiological findings from incidents of unusual mortality of the common frog (Rana temporaria). Philos Trans R Soc Lond B Biol Sci. 1996;351(1347):1539-57.

2. Glorioso JC, Amborski RL, Amborsky GF, Culley DD. Microbiological studies on septicemic bullfrogs (Rana catesbeiana). Am J Vet Res. 1974;35(9):1241-5.

3. Pasteris SE, Buhler MI, Nader-Macias ME. Microbiological and histological studies of farmed-bullfrog (Rana catesbeiana) tissues displaying red-leg syndrome. Aquaculture. 2006;251(1):11-8.

4. Mauel MJ, Miller DL, Frazier KS, Hines II, ME. Bacterial pathogens isolated from cultured bullfrogs (Rana catesbeiana). J Vet Diagn Invest. 2002;14:431-3.

5. Petrino T, Bulher MI, Legname A. Metabolic behaviour and activation capacity in the amphibian egg. Commun Biol. 1984;3:231-40.

6. Bauer AW, Kirby WM, Sherris JC, Turck M. Antibiotic susceptibility testing by a standardized single disk method. Amer J Clin Pathol. 1966;45(4):493-6.

7. Krumperman $\mathrm{PH}$. Multiple antibiotic resistance indexing of $E$. coli to identify highrisk sources of fecal contamination of foods. Appl Environ Microbiol. 1983;46(1):16570.

8. Miranda CD, Castillo G. Resistance to antibiotic and heavy metals of motile aeromonads from Chilean freshwater. Sci Total Environ. 1998;224(1-3):167-76.

9. Allen DA, Austin B, Colwell RR. Antibiotic resistance patterns of metal-tolerant bacteria isolated from an estuary. Antimicrob Agents Chemother. 1977;12(4):545-7.

10. McPhearson RM, DePaola A, Zywno SR, Motes ML, Guarino AM. Antibiotic resistance in gram-negative bacteria from cultured catfish and aquaculture ponds. Aquaculture. 1991;99:203-11. 